1959 年 Ovshinsky1) がカルコーゲンガラスの薄膜 で非破壞的スイッチング現象を見いだして以来，アモ ルファス無機半導体を用いたスイッチング素子が種々 開発されてきた。㐫る印加電圧を境にして，高抵抗状 態から準安定な低抵抗状態に非破壊的に変るという， いわゆるスイッチング現象は有機ポリマー薄膜につい ては無機物に比べかなり物くれて研究されはじあた。

著者らは，暗導電機構について比較的上く倹討され ているポリビニルカルバゾールを試料にえらび，分子 量やポリマー生成時の重合開始方法の影響, 不純物添 加効果, $\gamma$ 線照射効果，熱処理による結晶化の影響な どについてしらべ，スイッチング特性を左右する因子 を明かにする試みを行なった2。.

素子は蒸着金電極をガラス板につけ，その上にポリ ビニルカルバゾールのベンゼン溶液を塗布乾燥し, $0.1 \sim 1 \mu \mathrm{m}$ の薄い膜を作り，その上に金電極を蒸着し て，サンドイッチ型にした，この素子に值列に高抵抗 (1 $\mathrm{M} \sim 10 \mathrm{M} \Omega$ ) を入れ, 直流電圧を印加していくと, 最初は図のA点のようにほとんど電流が流れないが, 電圧を上げると電流は電圧の 2 乘に比例するようにな り，ついには，乙きい電圧 $B$ 点で急增し $\mathrm{C}$ 点で示す低 抵抗状態に移行する。この低抵抗状態は安定で，電圧 を下げると CからD点の方へ電流は変化し，いわゆる メモリースイッチング現象を示す。

電極金属がフォラメント状にポリマー膜中に入って いくとか，ポリマーにフィラメント状にジュール熱に 上る炭化が起こるとかいう現象が電子顕微鏡によって も見られないので,このスイッチング現象は純然たる 電子的機構によるものと推定している，高抵抗状態で の電流が SCLC 機構に従うとし, 浅いトラップのエ ネルギー分布が均一だとすると，トラップがみたされ 電流が急増する電圧 $V_{\mathrm{TFL}}$ は膜厚の 2 乗に比例し， ト ラップの密度に比例するはずである。この $V_{\mathrm{TFL}}$ がス イッチングを起こすしきい電圧と等しいと思われる.

となれば，このしきい電圧の大きさを左右するトラ ップの正体は何であるかが問題となる.

まず， $\gamma$ 線重合で得た分子量の異なる 2 種類のポリ ビニルカルバゾールを比較してみると, 分子量の小さ いポリマーの方がしきい電圧が高い，したがって，ポ リマー末端はトラップになる可能性大であることがわ かった.

次に,トラップになり得るものとして化学的不純物 が考えられるので，不純物添加効果をしらべてみた。

3 モル\%の $\mathrm{I}_{2}$ を加えた場合はしきい電圧が 2 倍にな ったが， 6 モル\%のテトラィチルーp-フェニレンジア ミン (TMPD) や 1,5-ジアミナフタレン (DAN) を 加光た場合は影響はなかった。暗電流は $\mathrm{I}_{2}$ で増加し， TMPD P DAN では減少した. AIBN で重合したポ リビニルカルバゾールは $\gamma$ 線重合で作った同じ分子量 のポリビニルカルバゾールに比べ，乙きい電圧が高 い.これはポリマー鎖末端についている触媒破片がト ラップになりやすいことを示している。

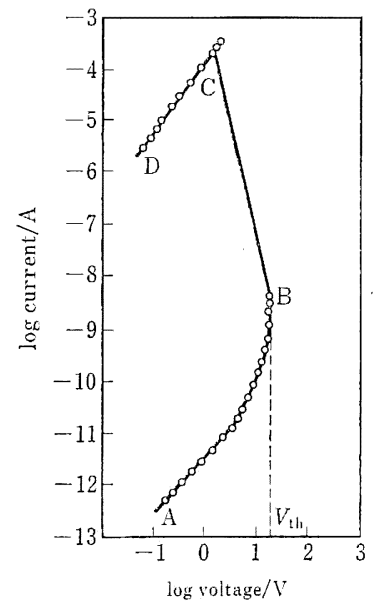

ポリビニルカルバゾールル $\gamma$ 線照射すると分子鎖が 切断されて分子量が低下寸る. スイッチング素子にし た後 線を照射した場合と, 粉末ポリマーを した後, 溶液にして成膜し素子にした場合とでは，前 者の方がしきい電圧が高い。つまり，照射によってで

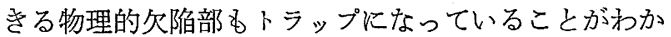
る. また照射によって生じた低分子量の不純物を精製 により除去すれば，しきい電圧はさがる.

熱処理によって結晶化度を上げると暗導電度は増加 するが，スイッテングのしきい電圧には何の変化もな い. しかしながら結晶化するとスイッチはしてもメモ リーする率が低下し，低抵抗状態がメモリーされてい ず印加電圧をゼロにすると元の高抵抗状態に回復して しまう，いわゆるしきいスイッチする率がふえる。

暗導電度に影響するトラップとスイッチングに影響 するトラップとは同一のものではない. 他の種々のポ リマーについても類似のスイッチング現象は起こる が，いずれの場合も素子の耐久性と再現性にはまだ解 決すべき問題が残っている.

\section{文献}

1) S.R. Ovshinsky : Electronics, 32, 76 (1959)

2) Y. Sakai, Y. Sadaoka, G. Okada : Polym. J., 15, 195, 663 (1983)

酒计義郎（愛湲大学工学部工業化学科・教授, 理博, 専門二機能性高分子材料, 化学センサー)

\title{
Switching Device
}

